\title{
Carl Schmitt's Turn to Sovereignty in Jurisprudence
}

\author{
Douglas Howland \\ Department of History, University of Wisconsin-Milwaukee, Wisconsin, USA \\ Email: dhowland@uwm.edu
}

How to cite this paper: Howland, D. (2018). Carl Schmitt's Turn to Sovereignty in Jurisprudence. Beijing Law Review, 9, 211-234.

https://doi.org/10.4236/blr.2018.92015

Received: April 12, 2018

Accepted: June 4, 2018

Published: June 7, 2018

Copyright (C) 2018 by author and Scientific Research Publishing Inc. This work is licensed under the Creative Commons Attribution International License (CC BY 4.0).

http://creativecommons.org/licenses/by/4.0/

\begin{abstract}
Carl Schmitt's early proposal to better unify the liberal state, by locating sovereignty in the executive, proved a disaster with the National Socialist regime. But sovereignty concerns a state's internal as well as international relations, and Schmitt came to argue in the 1940s that an authoritative and sovereign form of international law might offer standards for unifying states within an international community, much as the Catholic Church once provided an intra-state source of law and authority. Unlike recent work that emphasizes Nomos, Großraum, or "institutional thinking," this essay argues that Schmitt sought such a sovereign jurisprudence in the decisions of judges and justified it with the conservative claims of historical continuity.
\end{abstract}

\section{Keywords}

Authority of Law, Decisionism, Juristic Thought, Sovereign Jurisprudence

\section{Introduction}

Since the publication of an English translation of Carl Schmitt's The Nomos of the Earth in 2003, serious study of Schmitt's work has developed in two new directions. The field of International Relations has embraced Schmitt for his history of nomos-in particular, the period of "European public law"-and his concept of Großraum regions; these scholars find new ways to conceptualize international society (Hooker, 2009; Legg, 2011; Minca \& Rowan, 2016; Odysseos \& Petito, 2007). At the same time, motivated especially by the appearance of nomos in Schmitt's 1934 text, On the Three Types of Juristic Thought, legal scholars have sought to systematize Schmitt's life work as a "rational whole," by reconstructing its "inner logic" and revealing fundamental continuities (Croce \& Salvatore, 2013; Herrero, 2015). 
This recent work has much merit, for it enhances our understanding of Schmitt's ideas on the origins of law, its territorial and spatial contexts, and the place of "concrete-order" and "institutional thinking" in Schmitt's conception of law. Nonetheless, despite widespread attention to "decisionism" in Schmitt's treatment of law, it is perplexing that sovereignty has largely dropped out of the analysis. As these authors note, the authority of law was a central concern throughout Schmitt's career, but this essay begins by reminding us that Schmitt's emphasis on the authority of the decision was first analyzed in terms of sovereignty. What follows is an examination of Schmitt's endorsement of the state, his critique of the constitutional state, and then some of the solutions Schmitt imagined in his career. If his turn to the executive branch of government became a disaster in the person of Adolf Hitler, his most promising solution, I argue here, pursued instead the sovereignty of law and jurisprudence.

A number of scholars have recently attempted to situate Schmitt's turn to judges, legal education, and professional praxis as evidence of Schmitt's commitment to "institutional" or "concrete-order thinking," and these efforts have featured in descriptions of the continuity and wholeness of Schmitt's life work (Croce \& Salvatore, 2013: p. 5, 57; Herrero, 2015: p. 54, 61-65). But Schmitt had already in On the Three Types of Juristic Thought dismissed the concrete-order and communitarian thinking of an earlier age (Schmitt, 1934: pp. 75-81). ${ }^{1}$ Hence the following review of Schmitt's early work is meant not to engage the question of discontinuities in his life work, but to show the glimmer of a new approach during wartime. Although some recent literature has touched this possibility-most notably the excellent discussion of Schmitt's "institutionalism" by Jens Meierhenrich-this essay argues that Schmitt's turn to sovereignty in jurisprudence during World War II, because it emphasizes sovereignty, is not one in a series of institutional paradigms (Meierhenrich, 2016).

\section{The Problem of Authority}

To Carl Schmitt, the political crisis facing the constitutional state in the twentieth century was a disabling degree of disorder. Schmitt yearned for the communal order of the absolute state in early modern Europe, when command became law and the legitimate authority of sovereign power conferred a noble dignity upon the sovereign and enjoyed popular obedience below. Such unity and clarity of legal authority was lacking in the constitutional state, and Schmitt perceived the resulting confusion as demeaning to the sovereign power and purpose of the state. At its best, the constitutional state proceeded fitfully through a maze of private interests masquerading as those of "the people"; at its worst, the constitutional state was incapable of determining a course of action in managing a crisis.

Schmitt approached the problem of authority through an analysis of sovereignty. If the constitutional state were disabled by disunity, he was committed 
to recovering a theoretical and institutional basis for sovereignty and authority. And his approach has been described as "decisionist" on the basis of his assertion, "Sovereign is he who decides on the exception" (Schmitt, 1922: p. 5). Rather than examine an abstract concept of sovereignty, Schmitt turned to the sovereign power in action. He rejected the received treatments of nineteenth-century theorists of the state, such as J. K. Bluntschli or Alpheus Todd, who argued over definitions of sovereignty and its disposition within a constitution. Yes, one might thereby arrive at a common definition of sovereignty as "the highest legal power," but then one necessarily argued over concrete applications of such power. Instead, Schmitt insisted, let us pursue sovereignty in terms of "the sovereign" - who he is and what he decides to do in an emergency and how he eliminates the crisis (Schmitt, 1922: p. 7, 24-29). For the fundamental problem of sovereignty lies at the conjunction between actual power and the legally highest power: Who has the authority to decide? (Schmitt, 1922: pp. 16-18)

Schmitt thus reasoned that to understand sovereignty, we must look at the "state of exception," wherein the authority of the sovereign decision demonstrates the immanent validity of law. For Schmitt, such decisionism was the instance of authority and competence, and he perceived a causal chain set in motion by the sovereign decision, which determined norms. Where others might argue that legal norms participate in the ascription of right behavior, Schmitt argued instead that the authoritative decision determined the point of ascription, which in turn determined norms. Personal authority produced impersonal norms, and not the reverse (Schmitt, 1922: p. 31f; Schmitt, 1934: pp. 59-62; see also Scheuerman, 1994; Scheuerman, 1996; McCormick, 1997: pp. 121-156). ${ }^{2}$ Schmitt's understanding of this passage from exceptional circumstances to accepted norms offers a striking contrast both to the rational tradition of Locke and Kant, who ignored or marginalized the exception because it confounds unity and order, and to nineteenth-century rationalist legal thinking, which sought the objectivity of rational norms in place of subjective commands. Schmitt instead insisted that commands provided the basis for norms (Schmitt, 1922: p. 14). Moreover, Schmitt posed not a liberal problem of entitlement-of being duly elected or appointed-but the actual manifestation of making decisions, and thus his linkage of sovereignty and the exception invokes historical contingency and invites an authoritarian position. His decisionism is less a matter of decision-making than ultimate authority in exceptional circumstances: at the point of sovereign decision, authority equals power.

Or, as Heiner Bielefeldt and G. L. Ulmen have noted in their discussions of one of Schmitt's earliest works, Gesetz und Urteil(1912), Schmitt's initial motive was to "demonstrate that all legal justice necessarily rests on decisions which themselves can never be completely subordinated to positive or natural legal norms" (Bielefeldt, 1996: p. 380; see also Ulmen, 1985: pp. 10-15; Scheuerman, 1999: p. 22). The hiatus that always exists between general norms and particular ${ }^{2}$ For background on the concept of "state of exception," see Bielefeldt, 1996: 312f; for the relation of the exception to the origins of law, see Disegni, 2017. 
cases is bridged by the judicial decision, which should not be understood in terms of individualism - the deciding judge and his personality—but in terms of institutional procedures like collegial deliberation and binding precedents. Schmitt would return to this understanding periodically in his twisting career: that decisions might be informed by norms present in judicial practice and institutional procedures, but the decision "remains both the starting point and ultimate frame of reference for the entire system of legal justice" (Bielefeldt, 1996: p. 381; see also Benoist, 2007: p. 86f; Croce \& Salvatore, 2013: p. 57, 148; Herrero, 2015: p. 54f).

Nonetheless, the two limits within which Schmitt considered sovereignty as action cohered in such a way as to preserve Schmitt's ideal unity of authority and action. Both of these limits were borrowed from Hobbes, and both describe conditions more allegorical than actual. At one extreme, the absolute state epitomized a state of absolute sovereign power. In establishing a commonwealth, a people designated one or a group of their number to constitute the sovereign power; Hobbes describes this sovereign body as necessarily above the law of the land in order to enforce its absolute rule. At the other extreme, the state of nature-Hobbes's "war of all against all"-epitomized the pre-political condition of the sovereign individual, who acts with complete autonomy and authority to preserve his own life. To Hobbes, it was the danger that individuals posed to each other in the state of nature that prompted them to establish a commonwealth and thereby delegate sovereign power to the ruling body.

If Schmitt thus insists on thinking within parameters that confirm the absolute authority of sovereign action on the part of one actual or collective individual, it only makes sense that he found the liberal-democratic notion of "popular sovereignty" elusive and unrealizable. "The people" were typically a tempest of conflicting interests and, in practice, powerful minorities spoke on their behalf with partisan aims rarely perceived as legitimate. Moreover, Schmitt saw no value in the Anglo-American distrust of sovereign authority and the alternative preference for its dispersal among ideally balanced branches of government. Like Hobbes, he found such "mixed government" a faulty form prone to civil strife.

But the counterpart of this mythic "popular sovereignty" internal to the constitutional state was the very real sovereignty of that same state in international relations. If the internal manifestation of sovereignty was structurally unclear and practically elusive, once a sovereign decision had been made to go to war or to contract an alliance, the constitutional state could assume a greater, external coherence of purpose and action (Hooker, 2009: p. 18f). This was in part because the international domain persisted as a "state of nature"; and like the individual in a state of nature, the constitutional state pursued whatever course of action necessary in international relations to preserve its life, its people, and its territorial integrity. The absence of any ruling body and universal authority in international relations guaranteed the persistence of this international state of nature, and Schmitt occasionally considered this larger sphere of action as a potential 
source for solutions to the crisis of authority within parliamentary democracies.

\section{The State and Political Authority}

Before we pursue Schmitt's turn to an international context as an effort to resolve ambiguities surrounding authority, we must examine Schmitt's problematic idealization of the absolute state, which informed his yearning for order and stability. As an abstract form, the absolute state in theory is undermined by its history. For even as the sovereign authority of the monarch overcame the medieval estates and commanded a centralized jurisdiction, that very authority was undermined by the compromise with religion. As Schmitt relates the process in The Leviathan in the State Theory of Thomas Hobbes, the Protestant reformation may have confirmed the sovereign's authority in public religion, but it afforded an inward domain of private freedom that precipitated the bourgeoisie's constitutional attack on monarchy (Schmitt, 1938: p. 56, 61). Thus, on one hand, we have an absolute state that was declining in the midst of its rise: such an historical analysis refuses to justify Schmitt's multiple efforts at specifying an abstract form. But on the other hand, we have some persisting facts that inform Schmitt's analysis of these absolute states and do deserve a hearing: As Schmitt emphasized, the centralized monarchies of some absolute states-especially France and Prussia-did seek to dissolve the medieval estates and to establish centralized and authoritative jurisdictions that pursued the goals of both communal unity through hierarchy and public peace through obedience to law. It is these efforts of absolute states-and not an abstract form of the absolute state-that justifies Schmitt's interest in the early modern contrast to our constitutional states today (Schmitt, 1938: p. 71f, 79f, 96).

Schmitt's foregrounding of the state is critically significant. Given the recent four decades in the United States, for example, as neo-conservatives, libertarians, and neoliberals champion the assault on the putative intrusiveness of the federal government and vow to return government to local initiative, Schmitt's profound examination of the role of the state in twentieth-century national polities is a welcome and serious alternative to identity politics, market forces, or family values. Experience of a commonplace sort justifies Schmitt's look at the state: although many aspects of daily existence-the public peace and security for which the state was presumably founded-do reflect local conditions that vary from street to neighborhood, fundamental matters like health care, public transportation, voting rights, and declarations of war-which concern national communities-are in fact matters decided by the state. Its force in public life is paramount.

Schmitt asserted two key propositions in his analysis of the state, both of which are implicit in the preceding paragraph. First, the state became the fundamental unit of humanity in the twentieth century-a specific entity of "the people." It represents the political status of an organized people living in an enclosed territorial unit. As this essential political community, the state-defined 
as the public and political sphere-must be differentiated from society, which Schmitt understood as the sphere of private and pre-political interests (Schmitt, 1932: p. 19f). Schmitt's interest in rigorously differentiating state and society was not merely to beg the question of the subversive inter-penetration of the two under regimes of bourgeois constitutionalism. Rather, Schmitt's differentiation between state and society informed his second key proposition: that the state is the basis of what he called "the political," that most authoritative domain of human thought and experience (Schmitt, 1932: p. 19). Because the state's purpose is to maintain internal peace, security, and order, and to establish the "normal situation," the state thus decides in the extreme case to fulfill that purpose and chooses to go to war (Schmitt, 1932: p. 45f). Schmitt's provocative formulation for this authoritative decision was the friend-enemy distinction, which he insisted was to be seen not as metaphoric or symbolic but as deliberately concrete and existential, particularly as it is manifested in the extreme situation. It is the state that determines public and national enemies-necessarily an essentialization of political actions-in order to preserve itself in the case of most intense and extreme antagonism. But in less extreme manifestations, the state is also the source of administrative decisions, legal decisions, and jurisprudence (Schmitt, 1932: p. 21f, 26-30). Both the extreme and the routine, Schmitt noted in 1930, demonstrate that political unity is the highest form of unity today. For the state (through its officers) provides these key decisions (Schmitt, 1930: p. 203).

Schmitt made an important distinction between "the political" and "politics" that informs his most controversial understanding of the state. The political concerns the sovereign state with its people and territory and its determination of friend and enemy; while politics concerns instead those internal antagonisms over the state-as with "party politics" (Schmitt, 1932: pp. 27-29, 32; see also Hofmann, 2002: pp. 101-114). Hence politics is much more engaged in ideology than the political; but as it approaches matters of sovereignty, politics becomes more acute and "political." Schmitt's focus on the political, in other words, affirmed the function of the state: the state that preserves peace and security is performing its function, and the state may need to be intolerant to keep the peace-this is clear in that one aspect of the authority of the state is to recognize its enemy. Hence Schmitt argued that the state is neutral as a vehicle for maintaining peace, a goal which any regime can undertake. Citizens create a state for their mutual protection, and in return give their obedience (Schmitt, 1938: p. 42; Schmitt, 1929: p. 141). As Leo Strauss noted, Schmitt's concept of the political was an affirmation of both man's "dangerousness" - his need of dominion-and the state of nature (Strauss, 1932: p. 97f, 103).

Schmitt's pairing of sovereignty with the exceptional situation thus brings him to the kind of authoritarianism recommended by Hobbes. The war of all against all, which gives rise to the state, provides Schmitt with a model for the exception. The exception is that powerful moment at which-in spite of ongoing business-the friend-enemy distinction comes to the fore (Schmitt, 1932: p. 26f). 
Hence the exceptional has an important regulative power: it reminds us that the possibility of violence regulates the political, and it determines the difference between the "normal situation" and the exceptional. ${ }^{3}$ The exception is the moment that demands a manifestation of sovereign decision - an "exacting moral decision" (Schmitt, 1922: p. 65). If sovereignty exists along a continuum marked by the normal situation and the exception, points that correspond respectively to the domains of legality and the political, it is the exceptional situation that invites sovereignty to become political. In other words, Schmitt's foregrounding of state authority pointed to sovereignty as an authoritarian act, and he accordingly faulted liberal constitutionalism for minimizing both sovereignty and the political.

\section{The Crisis of the Constitutional State}

By foregrounding the state and its relation to both the national community and the domain of political decisions, Schmitt identified the central problem of our contemporary constitutional democracies as a fundamental disunity, which he most often characterized as a plurality of interests and political parties that "personify" the people and disable decision-making processes (Schmitt, 1928a: p. 26; Schmitt, 1967: p. 3, 8). As an unwelcome interpenetration of society and the state, such disunity subverted the purposes of the state. And Schmitt identified three key problems that undermined bourgeois constitutionalism as it had developed in the nineteenth century: one historical, a second structural, and a third theoretical.

In the first place, echoing a criticism made in the nineteenth century by the Italian republican Giuseppe Mazzini, the constitutional state was an eighteenth-century reaction to monarchy and a rejection of the possibility of enlightened despotism. What began as an aristocratic project ended by fracturing society, when the bourgeoisie, asserting themselves as representatives of the people (or "Third Estate"), set up a constitution that privileged bourgeois property rights and made an opposition of the working classes. Hence Schmitt judged bourgeois constitutionalism, already a historical anachronism at its inception, woefully ill-prepared for the social and political conflicts that faced states in the twentieth century (Schmitt, 1923a: p. 33; Schmitt, 1923b: p. 20, 33).

Second, Schmitt noted that structurally, the constitutional state is a people's state, and hence the legislative body was the foundation of government, where the people met to enact law. Although the capacity of such a congress, parliament, or diet to represent the people was already compromised in its bourgeois origins, Schmitt noted further procedural developments that contributed to the poor performance of such governments. In practice, as we have seen in the USA and elsewhere in past decades with changes of presidents and congressional majorities, the national (or federal) legislation enacted by the legislature, although intended to be enduring law, is compromised by the particular order of a current administration, when it chooses not to enforce certain laws. In addition to this

${ }^{3}$ For the development of Schmitt's concept of the exception, see McCormick, 1997: 133-151. 
potential subversion from the executive, a second subversion proceeds from the bureaucratization of the information-gathering processes that support the work of enacting legislation, as smaller committees and lobbyists removed from public scrutiny undertake the people's business and make public decisions. The state is made to serve society, with politics and ethics linked in subjugation to economics (Schmitt, 1923a: pp. 42-48; Schmitt, 1932: p. 60f). ${ }^{4}$ In general, Schmitt maintained, the ideal of public discussion among the people's representatives, if once the founding principle of parliamentarism, had degenerated largely into, on one hand, a multi-party race to win a majority, and on the other hand, a spoils system as public business became the object of party influence and compromise. If parliamentarism was once animated by discussion that sought to persuade others of the truth of opinions, this had become an empty formality (Schmitt, 1923a: pp. 4-7; see also Schwab, 1989: pp. 67-72).

A third problem with constitutional states, according to Schmitt, was an inappropriate pairing of parliamentarism and democracy, which he saw as two principles of government fundamentally at odds with each other. Schmitt argued that parliamentarism, as the foundational principle of bourgeois liberalism, represented the effort to legally restrict the power of kings so as to guarantee the domain of bourgeois rights and to insert a space for the people's participation in parliament-through the election of representatives. His powerful critique, The Crisis of Parliamentary Democracy, outlined the basic principles of parliamentarism, or liberalism: 1) an openness, instituted through freedom of the press, that checked the absolute, arbitrary and secretive power of princes; 2) a division of powers that replaced the absolute unity of the monarchy and created the possibility of an equilibrium achieved through negotiations; and 3) the parliamentary creation of the people's law through an open, public discussion that was to produce truth and justice and replace the force at the basis of monarchy (Schmitt, 1923a: pp. 36-49).

Democracy, to Schmitt, was a different project entirely. As the formal manifestation of the principle of popular sovereignty, democracy proposed a project of self-determination that equated the people with the state; in understanding the people as the national substance of the state, democracy was based on a principle of equality and homogeneity. Thus the self-determining people were one and equal; and foreigners, colonial subjects, and other "outsiders" were not the equals of this democratically constructed citizenry. Schmitt of course referred to Rousseau's "social contract" in evaluating democracy, and he faulted Rousseau for pairing the social contract with a homogenous people, as a grounding of the "general will" that was in turn identified as law. ${ }^{5}$ To the contrary, Schmitt ob-

${ }^{4}$ On the dominance of the economic, see Maus, 1997. By contrast, Scheuerman (1999: p. 39) argues that Schmitt's "crisis of parliamentarianism" is part of his broader "crisis of legal indeterminacy." ${ }^{5}$ In Verfassungslehre (1928) and Legalität und Legitimität (1932), however, Schmitt insisted in an idealist manner that homogeneity-which he defined most often as a common culture and set of values-was a prerequisite for political community: homogeneity defined a polity and thus preceded law and a constitution. For trenchant criticisms of this position, see Scheuerman, 1994: 22, 31, 74, 80-85; Dyzenhaus, 1997: 51-58; Dyzenhaus, 1999: 75-90; Preuss, 1999; Kirchheimer \& Leites, 1987. 
served, modern democracies in practice were composed of heterogenous peoples whose coherence depended on an identity posited between the governed and the governing, with the result that, far from a people's social contract producing a general will, democratic states found themselves committed to extending the franchise in order to encourage the people to identify with the state. ${ }^{6}$ The result was an indistinct "we-hood" more abstract than concrete, and amenable to any political purpose-both bourgeois and Bolshevik versions of "the people" were arguably the personifications of powerful minorities (Schmitt, 1923a: p. 16f). Given the degeneration of parliamentary deliberation into influence-peddling and spoils systems, the principle of democracy only eroded the legitimacy of liberal constitutionalism. As he put it, the problems remain "how the will of a people is formed" and the legitimacy of such a democratic constitution, which cannot be merely the will of a powerful minority (Schmitt, 1923a: pp. 8-13, 24-29; see also Keane, 1988). ${ }^{7}$ Schmitt astutely noted, as early as 1919 , that this erosion of constitutionalism, which rendered serious questions of political equality empty or indifferent, was beginning to divert matters of substantive inequality into the economic sphere-all of which encouraged what he called the American goal of substituting an allegedly unbiased economic management for the biased rule of politics (Schmitt, 1922: p. 65).

It is worthwhile noting Chantal Mouffe's insightful response to Schmitt's differentiation of liberalism and democracy, for she provides a useful example of how Schmitt's desire for order is often received today. Mouffe treats the difference between democratic and liberal logic in terms of an opposition of inclusion and exclusion. Democratic logic assumes an inclusive definition of "the people"-an expandable definition that is necessarily based on exclusion. The people are, for the time being, only those included among the citizenry. Liberal logic, by constrast, sets no external limit, so that exclusion seems contingent-not a real or enduring problem; "inclusion" is the fundamental procedure, as humanity is the ultimate basis of liberal order. To Mouffe, this paradox is perpetually negotiated and renegotiated in liberal democracy. Mouffe, in other words, offers the position that a perpetual critique of exclusion is at the heart of democracy; the play between incommensurate foundations leads to ever-changing dynamics of inclusion and exclusion-what she calls "different hegemonic articulations." Schmitt sees this paradox as self-destructive, because he wants a stable foundation for political order: political order is grounded in resolution, unity, or an orderly "normal situation". Because he imagines a loyalty in relation to unity, he wants some commitment to a self-conscious "we" who are the state. By contrast, Mouffe sees no need for a stable basis, and sees that it can be realized in conflict, dynamism, or contestation: political order is based on something mutable (Mouffe, 1999: pp. 42-44).

${ }^{6}$ Kirchheimer and Leites (1987: 161) reached an alternative conclusion in their critique of Schmitt-that "heterogeneity implies the necessity of protection" (under the rule of law).

${ }^{7}$ On the linkage from Schmitt's authoritarianism and the problem of popular "will-formation" to an incipient fascism; see Bielefeldt, 1996; Scheuerman, 1996; Slagstad, 1988. 
But to Schmitt, if democratic principles ultimately question the legitimacy of constitutional states, this is in part because of the legacy of the American and French revolutions in the late eighteenth century. As Schmitt noted, those revolutions, which were first to issue liberal declarations of rights and constitutions, insisted that only this sort of bourgeois constitution was a legitimate constitution. But in fact, the American and French revolutions redefined constitution. Hobbes, for example, had allowed the legitimacy of both "instituted" and "acquired" commonwealths-the former was a commonwealth by agreement, exemplified by the constitutional monarchy, while the latter was a kingdom (especially monarchy) either inherited through family lines or conquered by force. Where all states had once been understood to have one or the other such constitution, the bourgeois constitution eliminated from consideration Hobbes' category of acquired commonwealth (Hobbes, 1985: p. 228f, 239f, 251-256; see also Schmitt, 1938: p. 62f.; Schmitt, 1928a: p. 46f). Monarchies per se have ceased to be legitimate polities, but at the same time, because the legitimacy of a constitutional state is grounded in a revolutionary act of its people, the criterion of whether or not the constitution safeguards the set of bourgeois rights can be invoked to differentiate an allegedly genuine act of the people-as with the Constitution of the United States of America-from an allegedly spurious act of some false personification of the people. To its critics, for example, the Organic Law of the Central People's Government of the People's Republic of China (27 September 1949) is a false representation. ${ }^{8}$

Hence, Schmitt concluded, constitutional democracies were undermined by a profound disunity of personal and group interests masquerading as those of "the people." The consequences for the constitutional state as a rule of law were devastating. The major problem that occupied Schmitt was what he called a "crisis of state legality" in the course of the nineteenth and twentieth centuries-a fracture between legality and legitimacy brought on by the confluence of several factors. Law, formerly the sovereign's command, was transformed into state legislation under the authority of the parliament; at the same time, the turn to positive law in the nineteenth century began a simplification and acceleration of law-making that resulted in a mass of new laws. When coupled in turn with the erosion of parliamentary representation of the people, Schmitt argued, the legality of the constitutional state was disengaged from any sense of legitimacy. This crisis of state legality is manifested in a number of ways. The technical approach to positive law, informed by committees of experts, has encouraged a distinction between the law's objective meaning and the subjective intent of the legislator; but with the fragmentation of parliament into parties and factions, the intent of the collective legislator is a problematic site of obstructions and compromises. Accordingly, we presume the legality of law: it is perhaps the one impersonal and objective force bridging political strife, virtually the "objective reason of political unity." Or, as Schmitt noted, "the law is always wiser than the legislator" 
(Schmitt, 1943/44: pp. 47-49). But in asserting the legality of the status quo, we bracket legitimacy. If the historical legitimacy based on the continuity of the state has been replaced by the revolutionary legitimacy of "the people," constitutional states today, in efforts to maintain a linkage between legality and legitimacy, have turned either to procedures, as with the concept of "due process" in the USA or "institutional guarantee" in Europe, or to the notion of shared values integrating the law and the citizenry (Schmitt, 1943/44: pp. 66-69). Neither of these afforded Schmitt much confidence; his most interesting inclination, to which I turn shortly, was a turn to the scholarly traditions of jurisprudence.

A related problem, especially pertinent in light of the American stress upon individual rights, has been the way in which individualism challenges the constitutional state as a rule of law. Schmitt was, to be sure, deeply suspicious of individualism and asserted on several occasions that man was a communal being; he associated individualism with Protestant inwardness and the political consequences of such an abandonment of the world (Schmitt, 1923b: p. 50f). Schmitt abhorred the pluralist theory of the state, represented by the work of G. D. H. Cole and Harold Laski, which described the state as composed of associations and those in turn composed of individuals; each individual thus lived amidst multiple and overlapping groups and was embedded in various relations, obligations, and norms. To Schmitt, such a characterization threatened the ethical demands of the state, and he strongly disapproved of the willingness to represent such a pluralist state of affairs in terms of individual choice and autonomy. Since normative precedents are typically provided for individuals by their groups, Schmitt argued that the proper issue was not individual choice but social ethics, and the sovereignty of social groups versus the demands of the state. He noted pessimistically that although ethical individualism has its correlate in the concept of humanity - the individual has value as a human being-there was no correlate for the individual as a member of society, or, I would add, as a citizen of a state (Schmitt, 1930: pp. 196-199, 208; see also Hooker, 2009). Schmitt wanted the state to attract loyalty and proposed a duty towards statehood. From the standpoint of law, he reasoned, the individual disappears as an empirical entity. Because the positive law of the constitutional state is the unity of impersonal, supra-empirical rule and the state-itself a supra-individual idea-the relation posited between law and the individual paled before the all-important relation between the state and its law. As he concluded in an early essay, "everything lawful destroys everything individual" (Schmitt, 1917: p. 50; see also Caldwell, 1997: p. 112f; Meier, 2011: p. 140f).

In part, then, Schmitt's critique of parliamentarism is less a question of alternatives than a matter of recognizing the nature and limits of democracy. Even if the American and French revolutions spoke in the name of the people, there never has been such a "pure" parliamentarism per se. Hence an alternative way to view the crisis of sovereign authority in the constitutional state is in terms of its built-in project of reform. Given the structural problems of constitutional 
democracy, the solution that most such states pursue has been a perpetual program of reform - that rational, if interminable, progress toward a better realization of the governmental form (Schmitt, 1923a: p. 3, 76; see also Howland, 2005: pp. 138-140). A second alternative, popular uprisings-in the form of revolutions, general strikes, and popular referenda-are much more problematic in that they could be interpreted either as democratic movements against parliamentary government or as actions of an enemy against the state. Or simply as symptomatic of an ill-defined state-like the colonial state-which, to Schmitt, was largely a broker among economic interests (Schmitt, 1923a: p. 68f). The question to ponder, I suppose, in considering Schmitt's critique of the constitutional state is this: Is the chaos within contemporary states experienced as profoundly conflictual, such that society is always ready for civil violence, or as perpetually fragmented, such that government is incapable of decisions?

\section{An Attempt to Recover Sovereignty and Authority}

If the concept of sovereignty, which continues to bear its philological origin in the sovereign monarch, recalled for Schmitt the early modern state in which the sovereign's command was law and his legitimate authority commanded both a personal dignity and popular obedience, it is clear from the preceding section that the fundamental disunity of the constitutional state has rendered unlikely such a coherence of law, legitimacy, authority, and power. In the face of that status quo, Schmitt searched throughout his career for a means of recovering a basis for sovereign authority. I have observed three main strategies, each of which Schmitt developed intermittently in his writings prior to 1945: an elevation of the executive branch of government; an analysis of "mixed government" in order to recover what he called the liberal parliamentarism of the nineteenth century; and an endorsement of law and the European tradition of jurisprudence. $^{9}$

The first two of these strategies grew out of Schmitt's distrust of democracy and his desire to contain the people's manifold interests. Schmitt's earliest effort, his turn to the executive, reveals an initial ambivalence toward the role of democracy in the constitutional state. On the one hand, Schmitt was interested in the executive as a democratically legitimate challenge to constitutional dysfunction: the president or prime minister was elected by a parliamentary or popular majority and could thus claim legitimate sovereignty on the basis of democratic principle. Schmitt concluded from his analysis of constitutionalism that the legislature was the site of reasoned discussion and the executive thus the site of ac-

\footnotetext{
${ }^{9}$ As noted in the "Introduction" above, a possible fourth strategy was Schmitt's controversial "concrete-order" (Stände) theory, which proposed reviving medieval status orders (knights, farmers, burghers, clergymen) in the interests of a hierarchical unity of the whole, subject to the legal and ethical norms appropriate to each status. While some argue that it was a pointed effort to appeal to the Nazi government, others see a unifying concept of Schmitt's œuvre. See Schmitt, 1934: 90-94; and compare Herrero, 2015: 61-63; Hofmann, 2002: 177-87; Scheuerman, 1999: 122-126; and Schwab, 1989: 115-125.
} 
tion; this placed the executive in a theoretical position to manifest sovereign action (Schmitt, 1923a: p. 44f). When he evaluated the Weimar Constitution, Schmitt would argue that the Reichspräsident could legally claim emergency powers and so act with legitimate authority (see Balakrishnan, 2000: p. 143; Cristi, 1998: p. 8, 63).

But on the other hand, Schmitt's 1920s work on dictatorship offered an important linkage between the state of emergency and popular sovereignty, in such a way as to minimize the role of democracy. First, Schmitt noted sovereign decisionism in the "commissarial dictatorship," a conservative form derived from the example of the extraordinary magistrate under the Roman Republic, who was commissioned for the duration of an emergency. And second, he noted the sovereign capacity for action in the "sovereign dictatorship," a revolutionary form based on the provisional legislative assembly that dissolved the old constitution and proclaimed a new one in the name of the people-as had happened in the course of the French revolution as well as the Bolshevik revolution and its "dictatorship of the proletariat" (Schmitt, 1928a: pp. 130-152). Schmitt entertained the possibility that the people could manifest their revolutionary legitimacy by electing a dictator to manage the state in a time of crisis. Such a sovereign dictator ruled by decree and was not encumbered by the claims of democratic government. Hence, when he considered the formal components of the constitutional state-the democratic principle of the lower house, the aristocratic principle of the senate or peers, and the monarchical principle of the executive-Schmitt judged the executive a promising site of exceptional state powers, available for decisionism and dictatorship, the manifestations of a sovereignty that would unify the state (see especially McCormick, 1997: pp. 121-156; Balakrishnan, 2000: pp. 29-32; Caldwell, 1997: pp. 56-61, 98-101; Cristi, 1998: pp. 63-69; Scheuerman, 1999: pp. 30-35; Schwab, 1989: pp. 29-43). ${ }^{10}$

But such a solution to the crisis of authority in the constitutional state is evidence that Schmitt's yearning for order and authority could compromise his position and purpose as a political and legal theorist. Although Schmitt's promotion of the executive was first put forward in the midst of a German constitutional crisis in 1928-29, over the conflict of jurisdictions between the old, prewar Reich court and the new, federal (State) courts mandated by the Weimar Constitution, both this argument and his later, infamous support of the National Socialists grew from the same yearning. ${ }^{11}$ It clouded his political judgment in the 1930s, when he proposed "the movement"-led by Adolf Hitler-as a legitimating link between the people and the state, with disastrous personal and national consequences (Balakrishnan, 2000: pp. 139-43, 185). At the same time, the executive solution reminds us that Schmitt's decisionism was limited as a strictly

${ }^{10}$ On the relation of Schmitt's ideas on dictatorship to his 1931 work on "the guardian of the constitution," see Dyzenhaus, 1997: 76f.

${ }^{11} \mathrm{~A}$ second phase of the dispute over jurisdiction, specifically between the Reich and the state of Prussia, ensued in 1932; see Bendersky, 1983: 154-168; and Kennedy, 1983. 
formal treatment of the category of the political and sovereignty as decisive action. Although he disagreed with the monarchist "Ultras," the anarchists, and the Marxists, he could admire their political commitment and the moral center that motivated it-regardless of the content of those views-because it led to decisions (Schmitt, 1919: p. 119f; Schmitt, 1923b: p. 36f; Schmitt, 1923a: pp. 51-76). Hence Schmitt's involvement with the National Socialists makes somewhat of a moot point as to whether or not he shared their political views; his admiration for their decisive action-if only an aspect of an analytic project to understand the nature of the political-leaves Schmitt either an engager in realpolitik or an opportunist. $^{12}$

But Schmitt was simultaneously considering an alternative solution, based on a new look at the "mixed form" of the constitutional state. Although he denigrated the "mixed state" as an unworkable structure, his occasional willingness to take seriously the consequences of popular sovereignty facilitated a positive reconsideration of the division of powers. As Renato Cristi has argued, Schmitt's Verfassungslehre of 1928 provided an analysis of the people as the "constituent power" in establishing a constitutional state; this was his decisionist alternative to the commonplace argument that sovereignty rests on the constitution (Cristi, 1998: p. 109, 116-118). The idea of constituent power afforded Schmitt an analysis of the constitutive principles that informed the decision to create the bourgeois constitutional state. In the first place, such a state was composed of (a) a liberal element that provided for the division of powers and the rule of law so as to protect individual liberties against the state, and (b) a political element that provided the form of the state and hence secured the unity of the state (Cristi, 1998: pp. 126-29). In the second place, this political element was in turn informed by a principle of identity, which determines the people's political unity, and a principle of representation, which mediates the full and permanent presence of the people. Schmitt argued that the balance that had existed in the constitutional state in the nineteenth century, between identity and representation, had been distorted by democracy in the twentieth century. Where the aristocratic principle of government had once been used by the bourgeoisie as a mediating power in the state structure-through the principle of representation in both the upper and lower houses-the growing emphasis on democratic government compromised that principle of representation. Identity took precedence over representation, with the result that the "sovereign representation" of nineteenth-century parliamentary officials, who acted as independent agents on their own authority, had given way to a "delegate representation" in the democratic twentieth century; and such democratic officials were the dependent agents of private interests. Schmitt imagined a return to the earlier, liberal parliamentarism and thereby contain democratic parliamentarism; he wished that democracy

${ }^{12}$ For trenchant indictments of Schmitt's involvement with the Nazi regime, see Lilla, 1997; Müller, 2003: 17-47; Wolin, 1992; and Yamashita, 1986: 39-75. By far the most damning yet reasonable critique is Scheuerman, 1999: 113-139, 175-180. 
were not participatory but plebiscitary (Cristi, 1998: pp. 132-135, 206; see also Böckenförde, 1998: p. 49f; Manin, 1997: pp. 149-156; Kelly, 2004). ${ }^{13}$

Of course the abstractness of Schmitt's second solution-and the lack of a concrete proposal-do not afford a strong recommendation, nor does the fact that, in Cristi's telling (1998: p. 143), Schmitt abandoned the idea when he proclaimed the demise of the Weimar Constitution in support of the National Socialist revolution. But a limitation common to both of these solutions-the turn to the executive (and monarchical principle), and the revival of liberal parliamentarism (the aristocratic principle) - is that both looked backward in attempting to recover a lost unity and authority. Schmitt imagined overturning historical developments so as to retreat to earlier political forms. It is perhaps this limitation that makes his third solution to the crisis of authority so much more interesting a possibility.

This third solution that Schmitt imagined for the crisis of the constitutional state was a turn to the sovereignty of law. Schmitt repeatedly criticized the rise of legal positivism that had accompanied the bourgeois constitutional state, especially as it represented a managed legality intended to meet the needs of official and corporate bureaucracies (Schmitt, 1938: p. 67; see also Ulmen, 1985: pp. 7-10 for a placement of Schmitt in German legal theory). And he took seriously Marx's argument that constitutional law reflects bourgeois class interests, such that jurisprudence had been undermined by the bourgeois use of justice and freedom to legitimize one's own ambitions and disqualify those of others (Schmitt, 1932: p. 66f). Similarly, in light of the punitive measures leveled against Germany with the Versailles Treaty, he criticized the victors' use of "liberal" international law to criminalize the actions of defeated enemies; he charged that this development of "just war doctrine" sought to deprive the defeated of their sovereign right to settle claims through warfare, a right once accorded by the customary law of nations (Schmitt, 1932: pp. 45-52; Schmitt, 1985: pp. 33-37, 43-45; see also Balakrishnan, 2000: pp. 228-230; Kervégan, 1999: p. 59f; Scheuerman, 1999: pp. 142-146). These issues contributed to both Schmitt's diagnosis of a "crisis of state legality" and his doubts that the sovereignty of law was an obvious venue for solutions.

As an abstract proposition, the sovereignty of law seemed a reasonable interpretation of constitutional state order, but Schmitt argued that such a proposition was problematic because it did not concern the content of the law. From the perspective of sovereignty, the content of law and its enforcement depend on persons with authority who make decisions; it is they, and not the law, who invoke the power of the state. In that regard, Schmitt suggested that sovereignty could set the state and its law at odds with each other (Schmitt, 1922: p. 22f). Furthermore, in charging that the liberal constitutional state represses sovereignty and authority by a division and mutual control of powers, which are out-

${ }^{13}$ Cristi (1998: 102) covers the background of sovereign and delegate representation in Hegel; and Scheuerman (1996: 309f) has analyzed constituent power as exemplary of Schmitt's authoritarianism, as well as (1999: 68-71) indicative of a serious problem in liberal theory that deserves attention. 
side the interests of the legal system, Schmitt agreed with Hobbes that a "mixed government," in which sovereignty was divided, was self-destructive of the state. Both legislation and jurisprudence suffered when democratic populism displaced the independent action of sovereign representatives (Hobbes, 1985: pp. 368-372; Schmitt, 1923b: p. 26; see also Hirst, 1999).

These reservations aside, however, Schmitt imagined the law as the sole available means for overriding private interests. If the state of nature proceeded with each individual in possession of his sovereign right of nature - to defend his life and property with whatever force-then the state imposed the supra-individual force of law to govern all citizens equally. As Schmitt asserted, "The statement that all men are equal before the law has the accuracy of an analytic judgment, so that, if reversed, a law can be defined as that for which equality exists" (Schmitt, 1917: p. 50). The sovereignty of law, in other words, promised to ground the legal order of the state in a legitimacy more secure than popular sovereignty; and Schmitt's goal became a decisionism grounded in law, which made jurisprudence the primary legitimizing activity in the constitutional state. If sovereignty (in the person of the king) and legitimacy were once united in the absolute state, Schmitt wanted to reunite the sovereign authority of the law and its legitimacy. ${ }^{14}$

Schmitt's strategy for this project was disclosed in his wartime essay, "The Plight of European Jurisprudence," which promoted a striking confirmation of the scholarly tradition of jurisprudence. ${ }^{15}$ Presenting in part a historical sketch of jurisprudence, Schmitt located the origins of the European tradition in Roman law, which-as natural law, rational law, iusgentium, or general legal theory-provided the basis of both state law and international law in Europe. As the "first child of modern rationalism," because it had broken away from theology in the twelfth and thirteenth centuries, jurisprudence remained the last refuge of legal consciousness as it charted a path between, on one side, theology, metaphysics, and philosophy, and on the other, a merely technical craft. For it was the scholarly form of jurisprudence that had long revealed the unity of law and legal development, and thus Schmitt pronounced jurisprudence the "true source of law." Jurisprudence would safeguard the link between legality and legitimacy, and Schmitt invoked the early nineteenth-century precedent of Friedrich Carl von Savigny, who advocated the creation of a Germanic juridical estate to provide a unified legal authority for the many German states and principalities (Schmitt, 1943/44: p. 43, 54, 57, 64f; for an alternative view, see Carrino, 1999).

What is striking in Schmitt's essay is that he places the crisis of authority in the constitutional state within an international setting for reconsideration. In

\footnotetext{
${ }^{14}$ Herrero (2015), and Croce and Salvatore (2013), insist that a version of this project unites Schmitt's life work: the legitimacy of an autonomous law.

15 "Die Lage der europäischen Rechtswissenschaft" was first delivered as a lecture in 1943-44 and not published until 1950; hence scholars debate whether or not Schmitt altered it for opportunistic expedience after the war. See McCormick, 1997: 293-301; and Piccone and Ulmen, 1990: 14n.25, 16-19. Whether Schmitt did or did not "doctor" the essay does not change the fact of the argument as we have it, which, in my reading here, solves some of the problems he was considering in the late 1930s.
} 
this regard, "The Plight of European Jurisprudence" continues certain trajectories of Schmitt's concerns during the wartime dominance of National Socialism. In the first place, the essay extends what some scholars have identified as the anti-state position of Schmitt's accommodation to National Socialist goals, particularly his theory of the Großraum, the "large region" of a continental security bloc, dominated by a leading power. In the same way that the United States dominated the Americas, so too Germany would come to dominate Europe, and each such secure region would contribute to a more stable international order. Schmitt reasoned that modern technology and economic practices had undermined the simple territoriality of state sovereignty, and thus regionalism (even as it justified the German conquest of Europe) offered a more secure future than the liberal universalism imagined by the collective of eroding sovereign states (Schmitt, 1939b; Schmitt, 1941; see also Balakrishnan, 2000: pp. 234-240; Hooker, 2009: Ch. 6; Kervégan, 1999: pp. 61-64; and Scheuerman, 1999: pp. 148-152, 162-165).

In the second place, Schmitt's thinking on private international law during the early war years contributed both to his international reconsideration of the state and to a renewed seriousness with which he considered international law. Schmitt asked whether the validity of international private law depended on agreements between sovereign states, or whether it was valid prior to the state and its private law; and he began to conclude that certain rights did indeed predate the modern system of sovereign states. When laws became exclusively equated with statutes enacted by national legislatures, those national legal systems could come into conflict with the European interstate order if that national law abrogated the underlying rights embedded in the "common law" hitherto recognized by states. That is, the private law of international private law became more precarious as sovereign states-whose recognition for the attribute of sovereignty depended on the international order-claimed to be the exclusive source of law (Schmitt, 1939a; see also Balakrishnan, 2000: pp. 232-234). While Schmitt's interest in overriding the national laws of certain states can be interpreted as collusive with National Socialist takeovers of foreign states, we can also read his interest in international law as an effort to rethink the international order-a project that continued into the 1950s and 60s (Kervégan, 1999: p. 64, 67f). But as William Scheuerman has observed, while Schmitt's theory of Großraum might render international law irrelevant, one senses that Schmitt nonetheless continued to assume some liberal universalistic ideal as he considered the problem of international order (Scheuerman, 1999: p. 153, 164f).

Certainly, part of Schmitt's motivation in "The Plight of European Jurisprudence" was to recover some standard for statehood-he was writing at a time when he had already concluded that Germany was behaving like a "pirate" nation (see Balakrishnan, 2000: p. 240). International law, when it arose during the early modern period, was grounded in state law, which had originated with Roman law. There had, in other words, once existed a recognized community 
composed of different nations, whose members were united on the basis of a common European standard in codification, legislation, and justice. And the recognition of a state as a member of that community had once meant a measure of conformity to these standards-in effect, a standard of civilization. But in the nineteenth century, according to Schmitt, two processes had conspired to undermine the coherence of this community. First, the community united in an "international state law" had broken up with the fracture of that law into distinct bodies of state legislation and international accord. Second, the practice of international recognition of states had dissolved into a nihilistic opportunism with the rise of colonial empires, and made of recognition an arbitrary and tactical procedure (Schmitt, 1943/44: pp. 35-39, 42f).

In hoping to recover some unified standard, Schmitt made a positive principle of the homogeneity that had troubled him in discussing democracy. Where homogeneity was an erroneous assumption on the part of many theorists of the constitutional state, in terms of international relations it was a condition toward which states could and should work in order to forge a collective political existence (see Schmitt, 1928a: p. 54). And the basis of this homogeneity would be a common jurisprudence retaining a link to European traditions based in Roman law. Law would ground the equality theorized by democracy, and the community of states would work at homogeneity. Two aspects of this scenario are striking. In the first place, Schmitt's imagined judicial body of scholars, who would seemingly occupy a sovereign position of decision-making, is legitimized by historical continuity. ${ }^{16}$ Schmitt has ignored the revolutionary sovereignty of the people, suggesting that the continuity of legal institutions provides a steadier basis of state legitimacy. To put the point another way, Schmitt is placing his confidence in the proposition that revolutions are never so radical that they overturn fundamental traditions of state. In the second place, by proceeding to the international state of nature-outside of the constitutional state-in order to find a solution for the disunity of the latter, Schmitt was attempting to reassert some international authority as a check on the constitutional state. Even if a revolutionary people threw out the old constitution and proclaimed a new order, international standards might serve as a conservative guide for its more outrageous policies (see Schmitt, 1978).

Then as now, of course-and we are reminded that Schmitt lived through both the failed experiment of the League of Nations and the successful postwar establishment of the United Nations-the question was whether or not some international judiciary body would assume sovereign authority. Schmitt's occasional model for an international sovereign was the Catholic Church and its community. For Schmitt, the Church was an important mark of historical continuity both to Roman law, through its canon law, and to the political universal-

${ }^{16}$ Scheuerman (1999: 22-24) has identified this creation of legal homogeneity, by way of foregrounding the judge and his peers, as a motive in Schmitt's early Gesetz und Urteil (1912). The point is reiterated in Croce and Salvatore, 2013: 57, 148; and Herrero, 2015: 54f. 
ism of the Roman empire. He was especially enamored of the "formal" character of the Church: as both a juridical person and a personal representation of a concrete personality-the civitas humana-the Church manifested what Schmitt called the principle of "representation," an absolute realization of authority, the genuineness of which was confirmed by the hierarchy of authority in the Church and its embedment in traditions, social bonds, and real connections among people. Representation, Schmitt argued, invested the juridical person with a special dignity, and to Schmitt the Church was the sole surviving example of this medieval capacity to create "representative" figures. Although God, the people, or an idea like freedom could constitute a representation, once a state became a "leviathan"-became abstracted, alienated, and lost its connectedness to the people-it ceased to be a representation. It ceased to be a political possibility with the rise of the bourgeoisie, who fractured society into class oppositions. Where others might see a moribund, reactionary force in the Church, Schmitt saw a potential model for an international order. Had the League of Nations been invested with a sovereign power to decide, like that of the Church in its intra-state existence, it might have been able to substantiate its claim to authority and its partnership with states. For the juridical rationalism of the Church-manifested in its rational, institutional structure, and in the Pope as vicar, not prophet-had preserved a unity and order that checked the growth of sectarian fanatics within the Church community (Schmitt, 1928a: p. 27f; Schmitt, 1923b: p. 13, 31f, 35; see also Wani, 1990; Meierhenrich, 2016: pp. 188-191). Much as the Catholic Church once provided an intra-state ground for law and authority, so too a sovereign form of international law might recover some standard for unifying states within an international community.

\section{Conclusion}

Let me conclude by emphasizing Schmitt's comments on the authority of jurisprudence and the sovereignty of law in the context of the political. As I noted earlier, sovereignty in the constitutional state is located along a continuum, the endpoints of which are the exception and the normal situation, which correspond, respectively, to the domains of the political and legality. If we presume the legality of the normal situation, sovereignty is still most salient when it becomes political in the exceptional situation. What is interesting about Schmitt's analysis of constitutionalism is that the legitimacy of the state originates closer to the point of the exception, when sovereignty takes a political form-as when the people engage in revolution and assume their constituent power to establish a new state. Correspondingly, our efforts to identify legitimacy in the normal situation most often invoke legal procedure as a guarantee of justice and thus legitimacy. As Heiner Bielefeldt (1996: p. 383) put the point, legal normativity follows from political normality.

If we look outside of the constitutional state to the international arena, we find a similar relation between sovereignty and the political. Sovereignty is clearly 
manifested when the state determines to go to war-theoretically an exceptional situation-and, like the individual in the state of nature, defends its integrity with whatever force necessary. Although the USA, for example, has tried to make the sovereign act of declaring war the joint decision of both executive and legislative powers, most recently it has been the executive deciding and the legislature condoning his action. But this is to look at the state's external relations as an internal matter only. The problem, of course, is the constitutional state's external relations in the international context, where-in the business-as-usual as it transpires in the normal situation-states assert various forms of legality and custom on the grounds of international law, interstate treaties, and various accords. There is no sovereign judge whose authority might arrest the practices of outrageous states and sectarian fanatics, and this problem is all the more apparent in recent decades, as the nations of the world are faced with collective problems such as global climate change, refugees from local warfare, human rights abuses, the sale and dispersal of land mines, and so on.

Schmitt's notion of a sovereign international body with the authority to decide these matters is hence a compelling prospect. In addition to enforcing sovereignty in the normal situation - the legitimacy of international legality-such a body, composed of representatives of nations of the world, would be in a position to begin the work of homogenizing the international community. The problem, however, remains the intrusiveness of private interests masquerading as those of the public; and this is a much greater problem now than when Schmitt was writing in 1944, given the expansion of both multi-national corporations and partisan or guerilla forces that elude the oversight of states. But I would agree with Schmitt that law seems to be our sole available means of overriding private interests. An international jurisprudential authority would not only be in a position to enforce world standards in international relations, but it would also serve to check the bourgeois interests still dominant in dominant states like the USA, where policies on labor rights, medical care, the death penalty, and so on, still fail to meet civilized standards. Of course, as Schmitt noted, courts can certainly become politicized and defend private interests rather than public goods, but the solution, as Schmitt imagined, is to recover or reconstruct, under the leadership of jurists, national and international communities and a public representation united through a common legal tradition and stronger than any combination of private interests.

Moreover, Schmitt's proposal to pursue the reassertion of the sovereignty of law through the international setting promises to finally supplant his recurring and objectionable idealism with an engagement of a materialist praxis. ${ }^{17}$ As his Frankfurt School contemporaries observed, in spite of his repeated disdain for the abstract formalism and rationalism of Neo-Kantian scholars of the law like Hans Kelson, who promoted a normative theory of law, Schmitt himself retained a Neo-Kantian idealism that informed his criticism of liberal democracy and

${ }^{17}$ McCormick (1997: p. 297) calls this a "praxis that could reappropriate history." 
constitutional law. To Otto Kirchheimer, Schmitt's differentiation of democracy and liberalism was based on a pair of ideal-utopian axioms: an equality guaranteed by homogeneity and a freedom guaranteed by universality. Herbert Marcuse added that such homogeneity and universalism not only promoted an authoritarian set of predetermined and ideal values, but also contributed to a concept of totality that was rightly not axiomatic but the eventual resolution of a critical practice (Kirchheimer \& Leites, 1987; Marcuse, 1968; see also Habermas, 1989). ${ }^{18}$ Schmitt's turn to international law is thus a corrective move, as a constructive approach to homogeneity and authority in an effort to produce both standards of national and international behavior and thus the order and stability for which he yearned.

\section{References}

Balakrishnan, G. (2000). The Enemy: An Intellectual Portrait of Carl Schmitt. London: Verso.

Bendersky, J. W. (1983). Carl Schmitt: Theorist for the Reich. Princeton, NJ: Princeton University Press.

Benoist, A. (2007). Global Terrorism and the State of Permanent Exception. In Odysseos, \& Petito (Eds.), The International Thought of Carl Schmitt (pp. 73-96). London: Routledge.

Bielefeldt, H. (1996). Deconstruction of the "Rule of Law": Carl Schmitt's Philosophy of the Political. Archiv für Rechts und Sozialphilosophie, 82, 379-396.

Böckenförde, E.-W. (1984). Konkretes Ordnungsdenken. In J. Ritter, \& K. Gründer (Eds.), Historisches Wörterbuch der Philosophie (Vol. 6, pp. 1312-1315). Basel: Schwabe.

Böckenförde, E.-W. (1998). The Concept of the Political: A Key to Understanding CarlSchmitt's Constitutional Theory. In D. Dyzenhaus (Ed.), Law as Politics: Carl Schmitt's Critique of Liberalism (pp. 37-55). Durham: Duke University Press.

Caldwell, P. C. (1997). Popular Sovereignty and the Crisis of German Constitutional Law: The Theory and Practice of Weimar Constitutionalism. Durham: Duke University Press.

Carrino, A. (1999). Carl Schmitt and European Juridical Science. In C. Mouffe (Ed.), The Challenge of Carl Schmitt (pp. 180-194). London: Verso.

Cristi, R. (1998). Carl Schmitt and Authoritarian Liberalism: Strong State, Free Economy. Cardiff: University of Wales Press.

Croce, M., \& Salvatore, A. (2013). The Legal Thought of Carl Schmitt. New York, NY: Routledge.

Disegni, M. (2017). Über den Ursprung des Rechts. Carl-Schmitt-Studien, 1, 55-82.

Dyzenhaus, D. (1997). Legality and Legitimacy: Carl Schmitt, Hans Kelsen, and Hermann Heller in Weimar. New York, NY: Oxford University Press.

Dyzenhaus, D. (1999). Putting the State Back in Credit. In C. Mouffe (Ed.), The Challenge of Carl Schmitt (pp. 75-90). London: Verso.

${ }^{18}$ On the engagement between Schmitt and the Frankfurt School, see Scheuerman, 1994. On Schmitt's idealism and weakness at providing convincing historical contexts for his ideas, see Scheuerman, 1999: 18, 53-56, 66f. 
Habermas, J. (1989). The Horrors of Autonomy: Carl Schmitt in English. In S. W. Nicolsen (Ed.), The New Conservatism: Cultural Criticism and the Historians' Debate (pp. 128-139). Cambridge, MA: MIT Press.

Herrero, M. (2015). The Political Discourse of Carl Schmitt: A Mystic of Order. London: Roman \& Littlefield.

Hirst, P. (1999). Carl Schmitt's Decisionism. In C. Mouffe (Ed.), The Challenge of Carl Schmitt (pp. 7-17). London: Verso.

Hobbes, T. (1985). Leviathan. London: Penguin Books.

Hofmann, H. (2002). Legitimität gegen Legalität: Der Weg der politischen Philosophie Carl Schmitts (2nd ed.). Berlin: Duncker\&Humblot.

Hooker, W. (2009). Carl Schmitt's International Thought: Order and Orientation. Cambridge: Cambridge University Press. https://doi.org/10.1017/CBO9780511691683

Howland, D. (2005). Personal Liberty and Public Good. Toronto: University of Toronto Press. https://doi.org/10.3138/9781442678378

Kahn, P. W. (1997). The Reign of Law: Marbury vs. Madison and the Construction of America. New Haven, CT: Yale University Press.

Kaiser, J. (1989). Konkretes Ordnungsdenken. In H. Quaritsch (Ed.), Complexio Oppositorum, über Carl Schmitt (pp. 312-340). Berlin: Duncker \& Humblot.

Keane, J. (1988). Dictatorship and the Decline of Parliament. In Democracy and Civil Society (pp. 73-109). London: Verso.

Kelly, D. (2004). Carl Schmitt's Theory of Representation. Journal of the History of Ideas, 65, 113-134.

Kennedy, E. (1983). Review of Bendersky, Carl Schmitt: Theorist for the Reich. History of Political Thought, 4, 579-589.

Kervégan, J.-F. (1999). Carl Schmitt and "World Unity". In C. Mouffe (Ed.), The Challenge of Carl Schmitt (pp. 54-74). London: Verso.

Kirchheimer, O., \& Nathan, L. (1987). Remarks on Carl Schmitt's Legalität und Legitimität. In O. Kirchheimer, F. Neumann, \& K. Tribe (Eds.), Social Democracy and the Rule of Law (pp. 149-178). London: Allen \& Unwin.

Legg, S. (2011). Spatiality, Sovereignty, and Carl Schmitt: Geographies of the Nomos. New York, NY: Routledge.

Lilla, M. (1997). The Enemy of Liberalism. New York Review of Books, 44, 38-44.

Manin, B. (1997). The Principles of Representative Government. Cambridge: Cambridge University Press. https://doi.org/10.1017/CBO9780511659935

Marcuse, H. (1968). The Struggle against Liberalism in the Totalitarian View of the State. In His Negations: Essays in Critical Theory (pp. 3-42). Boston: Beacon.

Maus, I. (1997). The 1933 “Break” in Carl Schmitt's Theory. Canadian Journal of Law and Jurisprudence, 10, 125-140.

McCormick, J. P. (1997). Carl Schmitt's Critique of Liberalism. Cambridge: Cambridge University Press. https://doi.org/10.1017/CBO9780511608988

Meier, H. (2011). The Lesson of Carl Schmitt: Four Chapters on the Distinction between Political Theology and Political Philosophy (Trans. Marcus Brainard). Chicago, IL: University of Chicago Press.

Meierhenrich, J. (2016). Fearing the Disorder of Things. In J. Meierhenrich, \& O. Simons (Eds.), The Oxford Handbook of Carl Schmitt (pp. 171-216). Oxford: Oxford University Press. https://doi.org/10.1093/oxfordhb/9780199916931.013.30 
Minca, C., \& Rory, R. (2016). On Schmitt and Space. New York, NY: Routledge.

Mouffe, C. (1999). Carl Schmitt and the Paradox of Liberal Democracy. In C. Mouffe (Ed.), The Challenge of Carl Schmitt (pp. 38-53). London: Verso.

Müller, J.-W. (2003). A Dangerous Mind: Carl Schmitt in Post-War European Thought. New Haven, CT: Yale University Press.

Odysseos, L., \& Petito, F. (2007). The International Thought of Carl Schmitt. New York, NY: Routledge.

Piccone, P., \& Ulmen, G. L. (1990). Schmitt's “Testament” and the Future of Europe. Telos, No. 83, 3-34.

Preuss, U. K. (1999). Political Order and Democracy: Carl Schmitt and His Influence. In C. Mouffe (Ed.), The Challenge of Carl Schmitt (pp. 155-179). London: Verso.

Scheuerman, W. E. (1994). Between the Norm and the Exception: The Frankfurt School and the Rule of Law. Cambridge, MA: MIT Press.

Scheuerman, W. E. (1996). Carl Schmitt's Critique of Liberal Constitutionalism. The Review of Politics, 58, 299-322.

Scheuerman, W. E. (1999). Carl Schmitt: The End of Law. Lanham: Rowman \& Littlefield.

Schmitt, C. (1917). The Visibility of the Church: A Scholastic Consideration. In Roman Catholicism and Political Form (pp. 45-61, Trans. G. L. Ulmen). Westport: Greenwood, 1996.

Schmitt, C. (1919). Political Romanticism (Trans. Guy Oakes). Cambridge, MA: MIT Press, 1986.

Schmitt, C. (1922). Political Theology (Trans. George Schwab). Cambridge, MA: MIT Press, 1985.

Schmitt, C. (1923a). The Crisis of Parliamentary Democracy (Trans. Ellen Kennedy). Cambridge, MA: MIT Press, 1985.

Schmitt, C. (1923b). Roman Catholicism and Political Form (Trans. G. L. Ulmen). Westport: Greenwood, 1996.

Schmitt, C. (1928a). The Constitutional Theory of Federalism (Trans. G. L. Ulmen). Telos, No. 91, 26-56.

Schmitt, C. (1928b). Die Diktatur: Von den Anfängen des modernen Souveränitätsgedanken bis zum proletarischen Klassenkampf(2nd ed). München: Duncker\&Humblot.

Schmitt, C. (1929). The Age of Neutralizations and Depoliticizations (Trans. M. Konzett and J. P. McCormick). Telos, No. 96, 130-142.

Schmitt, C. (1930). Ethic of State and Pluralistic State (Trans. David Dyzenhaus). In C. Mouffe (Ed.), The Challenge of Carl Schmitt (pp. 195-208). London: Verso, 1999.

Schmitt, C. (1932). The Concept of the Political (Trans. George Schwab). Chicago: University of Chicago Press, 1996.

Schmitt, C. (1934). On the Three Types of Juristic Thought (Trans. J. W. Bendersky). Westport: Praeger, 2004.

Schmitt, C. (1938). The Leviathan in the State Theory of Thomas Hobbes (Trans. George Schwab \& Erna Hilfstein). Westport: Greenwood, 1996.

Schmitt, C. (1939a). Über die zwei grossen “Dualismen” des heutigen Rechtssystems. In Positionen und Begriffeim Kampf mit Wiemar-Genf-Versailles 1923-1939 (pp. 261-271). Berlin: Duncker \& Humblot, 1940.

Schmitt, C. (1939b). Völkerrechliche Großraumordnung mit Interventionsverbot für raumfremde Mächte: Ein Beitrag zum Reichsbegriff im Völkerrecht. Berlin: Deutscher 
Rechtsverlag.

Schmitt, C. (1941). Raum und Großraum im Völkerrecht. In G. Maschke (Ed.), Staat, Großraum, Nomos: Arbeiten aus den Jahren 1916-1969. Berlin: Duncker \& Humblot, 1995. https://doi.org/10.3790/978-3-428-47471-4

Schmitt, C. (1943/44). The Plight of European Jurisprudence (Trans. G. L. Ulmen). Telos, No. 83, 35-70.

Schmitt, C. (1967). The Tyranny of Values (Trans. Simona Draghici). Washington DC: Plutarch Press, 1996.

Schmitt, C. (1978). The Legal World Revolution (Trans. G. L. Ulmen). Telos, No. 72, 73-89.

Schmitt, C. (1985). Die Wendung zum diskriminierenden Kriegsbegriff (2nd ed.). Berlin: Duncker \& Humblot.

Schwab, G. (1989). The Challenge of the Exception: An Introduction to the Political Ideas of Carl Schmitt between 1921 and 1936 (2nd ed.). Westport: Greenwood.

Slagstad, R. (1988). Liberal Constitutionalism and Its Critics: Carl Schmitt and Max Weber. In J. Elster, \& R. Stagstad (Eds.), Constitutionalism and Democracy (pp. 103-129). Cambridge, MA: Cambridge University Press.

https://doi.org/10.1017/CBO9781139173629.005

Strauss, L. (1932). Notes on Carl Schmitt, The Concept of the Political. In The Concept of the Political (pp. 81-107, Trans. J. Harvey Lomax). Chicago: University of Chicago Press, 1996.

Ulmen, G. L. (1985). The Sociology of the State: Carl Schmitt and Max Weber. State, Culture, and Society, 1, 3-57.

Wani, A. (1990). Kyōkai, kōhōgaku, kokka: Shoki Kāru Shumitto no kōhōgaku. [The Church, Public Law, and the State: Public Law in the Early Carl Schmitt.] Tokyo: Tokyo Daigaku shuppankai.

Wolin, R. (1992). Carl Schmitt: The Conservative Revolutionary, Habitus and the Aesthetics of Horror. Political Theory, 20, 424-447.

Yamashita, T. (1986). Kāru Shumitto kenkyū: Kiki seifu to hoshu kakumei undō. [Studies on Carl Schmitt: Emergency Government and the Conservative Revolutionary Movement.] Tokyo: Nansōsha. 